\title{
ЕКОНОМІЧНІ АСПЕКТИ РЕАЛІЗАЦІЇ АВТОНОМНИХ ЗАРЯДНИХ СТАНЦІЙ ЕЛЕКТРОМОБІЛІВ НА ОСНОВІ ВІТРОЕЛЕКТРИЧНИХ УСТАНОВОК
}

\author{
В.І. Будько ${ }^{1,2}$, канд. техн. наук, доцент, С.О. Кудря ${ }^{2,1}$, чл.-кор. НАН України, докт. техн. наук, проф., С.В. Войтко ${ }^{1}$, докт. \\ екон. наук, проф., О.О. Трофименко ${ }^{1}$, канд. екон. наук, доцент

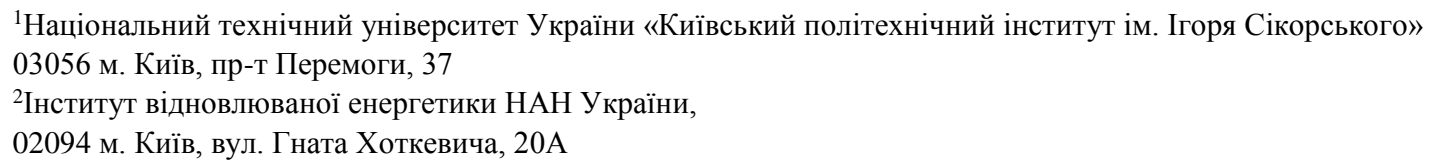

Проаналізовано об 'єми виробітку електроенергї в Украӥні за минулий рік, а також динаміку приросту електроспожсивання в порівнянні з попереднім роком. Розглянуто сучасний стан розвитку об’єктів відновлюваної енергетики Украйни та відмічено, щуо суттєвий приріст фотоелектричних та вітроелектричних станцій обумовлений через найвищі коефіцієнти «зеленого тарифу», які діють на продаж екологічно чистої електроенергії. При иъьму показано, щуо темпи збільшення потужностей вітроелектричних станцій суттєво поступаються фотоелектричним станціям. Відмічено, щзо вітроенергетичний потениіал Украйни значно перевищує енергетичний потенціал сонячного випромінювання. Враховуючи швидко зростаючу динаміку приросту електромобілів на території України обтрунтована необхідність прискорення темпів використання енергетичного потенціалу вітру України через реалізацію автономних зарядних станцій електромобілів з вітроелектричними установками. Розглянута спадаюча динаміка індексу вартості вітроелектричних установок та літієвих акумуляторних батарей. Визначені основні капіталовкладення для реалізації системи автономної зарядної станиії електромобіля з вітроелектричними установками та буферними акумуляторами енергії. На основі аналізу сезонного характеру зміни виробітку вітроелектричних установок, а також тарифної політики на продаж електричної енергії при заряді електромобілів встановлено, щзо термін окупності реалізації автономної зарядної станції даного типу може складати від 9-10 до 19-20 років. Відмічено, що показник гарантованого заряду електромобіля буде максимальним тільки за умови рівномірного розподілу швидкості вітру протягом року. Бібл. 8, рис. 4.

Ключові слова: вітроелектрична установка, автономна зарядна станиія, електромобіль, буферна акумуляторна батарея.

\section{ECONOMIC ASPECTS OF REALIZATION OF AUTONOMOUS CHARGER STATIONS OF ELECTRIC VEHICLES ON THE BASIS OF WIND TURBINE}

V. Budko ${ }^{\mathbf{1}, 2}$, candidate of technical science, assistant professor, S. Kudria ${ }^{\mathbf{2 1}}$, corresponding member of the NAS of Ukraine, doctor of technical science, professor, S. Voitko ${ }^{1}$, doctor of economic sciences, professor, O. Trofymenko ${ }^{1}$, candidate of economic sciences, assistant professor.

${ }^{1}$ National Technical University of Ukraine «Igor Sikorsky Kyiv Polytechnic Institute» 03056, 37 Peremohy Avenue, Kyiv, Ukraine ${ }^{2}$ Institute of Renewable Energy, NAS of Ukraine 02094, 20A Hnata Khotkevycha Street, Kyiv, Ukraine.

The volumes of electricity generation in Ukraine for the last year, as well as the dynamics of growth of electric consumption in comparison with the previous year have been analyzed. The current state of development of renewable energy objects of Ukraine is considered, and it is noted that a significant increase in photovoltaic and wind power plants is due to the highest coefficients of the "green tariff" that are valid for the sale of clean energy. It is shown that the rates of increase of capacities of wind power plants are significantly inferior to photoelectric stations. It is noted that the wind energy potential of Ukraine significantly exceeds the energy potential of solar radiation. Taking into account the rapidly growing dynamics of electric vehicle growth in Ukraine, the need to accelerate the use of the energy potential of Ukraine's wind through the implementation of autonomous charging stations of electric vehicles with wind turbines has been substantiated. The downward dynamics of the cost index of wind power plants and lithium-ion batteries is considered. The basic investments for realization of the system of an autonomous charging station of an electric motor with wind power plants and buffer batteries of energy are determined. On the basis of the analysis of the seasonal nature of the change in the production of wind power plants, as well as the tariff policy for the sale of electric energy at the charge of electric vehicles, it has been established that the payback period for the sale of an autonomous charging station of this type may be from 9-10 to 19-20 years. It is noted that the index of the guaranteed electric vehicle charge will be maximal only if the wind speed distribution is evenly distributed during the year. Ref. 8, fig. 4.

Keywords: wind turbine, autonomous charging station, electric vehicle, buffer battery. 



C.В. Войтко

S. Voitko
Відомості про автора: доцент кафедри Відновлюваних джерел енергії Національного технічного університету України «Київський політехнічний інститут імені Ігоря Сікорського» (КПІ ім. Ігоря Сікорського), кандидат технічних наук, старший науковий співробітник відділу вітроенергетики Інституту відновлюваної енергетики НАН України.

Освіта: Національний технічний університет України «Київський політехнічний інститут», інженер-технолог за фахом «Технічна електрохімія».

Наукова сфера: Системи накопичення і зберігання енергії на основі електрохімічних акумуляторів; комплексні системи енергозабезпечення на основі відновлюваних джерел енергії; підвищення ефективності роботи автономних вузлів енергопостачання на основі відновлюваних джерел енергії.

Публікації: 52. Патенти: 3 .

ORCID: 0000-0002-6219-4221

Контакти: +38 (044) 204-81-91

e-mail: solar_budko@ukr.net

Відомості про автора: директор Інституту відновлюваної енергетики НАН України, виконувач обов'язки завідувача кафедри відновлюваних джерел енергії Національного технічного університету України «Київський політехнічний інститут імені Ігоря Сікорського» (КПІ ім. Ігоря Сікорського), чл.-кор. НАН України, доктор технічних наук, професор кафедри відновлюваних джерел енергії КПІ ім. Ігоря Сікорського.

Освіта: Київський політехнічний інститут, інженер-технолог за спеціальністю «Технології електрохімічних виробництв».

Наукова сфера: комплексні системи енергозабезпечення на основі відновлюваних джерел енергії; системи акумулювання та перетворення енергії відновлюваних джерел.

Публікації: 332.

Патенти: 45.

Монографії: 11.

ORCID: 0000-0002-4798-6853

Контакти: +38 (044) 206-28-09

e-mail: sa.kudria@gmail.com

Відомості про автора: завідувач кафедри міжнародної економіки Національного технічного університету України «Київський політехнічний інститут імені Ігоря Сікорського» (КПІ ім. Ігоря Сікорського), доктор економічних наук, професор кафедри міжнародної економіки КПІ ім. Ігоря Сікорського.

Освіта: Національний технічний університет України «Київський політехнічний інститут», інженер-конструктор-технолог за фахом «Конструювання і технологія радіоелектронних засобів».

Наукова сфера: економіка підприємства, економіка енергетичної сфери, міжнародна економіка, управління розвитком наукомістких підприємств, Індустрія-4.0.

Публікації: 510.

ORCID: 0000-0002-2488-3210

Контакти: +38 (044) 204-91-03

e-mail: s.voytko@kpi.ua
Author information: Associate Professor of the Department of Renewable Energy of the National Technical University of Ukraine "Igor Sikorsky Kyiv Polytechnic Institute" (Igor Sikorsky KPI), PhD of Technical sciences, senior researcher the Department of Wind Energy the Institute of Renewable Energy of the National Academy of Sciences of Ukraine.

Education: National Technical University of Ukraine "Kiev Polytechnic Institute", engineertechnologist in the specialty "Technical Electrochemistry".

Research area: Systems of accumulation and storage of energy based on electrochemical battery; Integrated energy supply systems based on renewable energy sources; Increasing the efficiency of autonomous power supply units on the basis of renewable energy sources.

Publications: 52. Patents: 3.

ORCID: 0000-0002-6219-4221

Contacts: +38 (044) 204-81-91

e-mail: solar_budko@ukr.net

Author information: Director of the Institute of Renewable Energy of the National Academy of Sciences of Ukraine, Acting Head of the Department of Renewable Energy Sources of the National Technical University of Ukraine "Igor Sikorsky Kyiv Polytechnic Institute" (Igor Sikorsky Kyiv Polytechnic Institute), Corr. NAS of Ukraine, Doctor of Technical sciences, Professor of the Department of Renewable Energy Sources of the Igor Sikorsky Kyiv Polytechnic Institute.

Education: Kyiv Polytechnic Institute, engineertechnologist on the specialty "Technologies of electrochemical manufactures".

Research area: integrated power supply systems based on renewable energy sources; systems of energy storage and conversion of renewable sources.

Publications: 332

Patents: 45.

Monographs: 11.

ORCID: 0000-0002-4798-6853

Contacts: +38 (044) 206-28-09

e-mail: sa.kudria@gmail.com

Author information: Head of the Department of International Economics of the National Technical University of Ukraine "Igor Sikorsky Kyiv Polytechnic Institute" (Igor Sikorsky Kyiv Polytechnic Institute), Doctor of Economic sciences,Professor of the Department of International Economics of Igor Sikorsky Kyiv Polytechnic Institute.

Education: National Technical University of Ukraine "Kiev Polytechnic Institute", engineerdesigner-technologist on the specialty "Design and technology of radio-electronic means".

Research area: the economy of the enterprise, the economy of energy sector, the international economy, the management of the development of knowledge-intensive enterprises.

Publications: 510.

ORCID: 0000-0002-2488-3210

Contacts: +38 (044) 204-91-03

e-mail: s.voytko@kpi.ua 


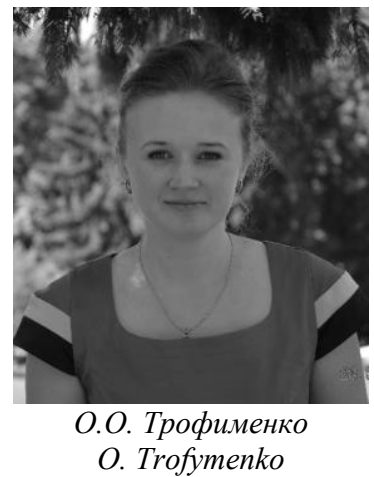

O. Trofymenko
Відомості про автора доцент кафедри теоретичної та прикладної економіки Національного технічного університету України «Київський політехнічний інститут імені Ігоря $\mathrm{Ci}$ корського» (КПІ ім. Ігоря Сікорського), кандидат економічних наук, відповідальний секретар наукового журналу «Підприємництво та інновації».

Освіта: Національний технічний університет України «Київський політехнічний інститут», за спеціальністю «Менеджмент організацій». Наукова сфера: економіка підприємства, економіка енергетичної сфери, управління розвитком енергетичних підприємств.

Публікації: 35 .

ORCID: 0000-0002-2339-0377

Контакти: +38 (044) 204-85-07

e-mail: o.o.trofymenko@gmail.com
Author information: Associate professor of the Department of International Economics of the National Technical University of Ukraine "Igor Sikorsky Kyiv Polytechnic Institute" (Igor Sikorsky Kyiv Polytechnic Institute), PhD of Economic sciences, responsible secretary of the scientific journal "Entrepreneurship and Innovation".

Education: National Technical University of Ukraine "Kiev Polytechnic Institute", in the specialty "Management of Organizations".

Research area: enterprise economy, the economy of energy sector, the management of the development of energy enterprises.

Publications: 35 .

ORCID: 0000-0002-2339-0377

Контакти: +38 (044) 204-85-07

e-mail: o.o.trofymenko@gmail.com
Перелік використаних позначень та скорочень:

ВДЕ - відновлювані джерела енергії;

АЗСЕМ - автономна зарядна станція електромобілів;

ОЕС - об'єднана енергосистема;

ВЕУ - вітроелектрична установка;

Вступ. Виробіток електроенергії за 2018 рік в Україні склав 146,11 млрд кВт·год. У загальному обсязі виробництва електроенергії 1,9\% (2,78 млрд кВт·год) було вироблено об'єктами відновлюваної енергетики, а ії частка у вартості склала $8,61 \%$ [1]. За останній рік суттєвих змін не сталося. Зросли тільки обсяги виробництва електроенергії на 2,7 \% порівняно з 2017 роком, проте співвідношення обсягів споживання населенням і промисловістю практично не змінилося.

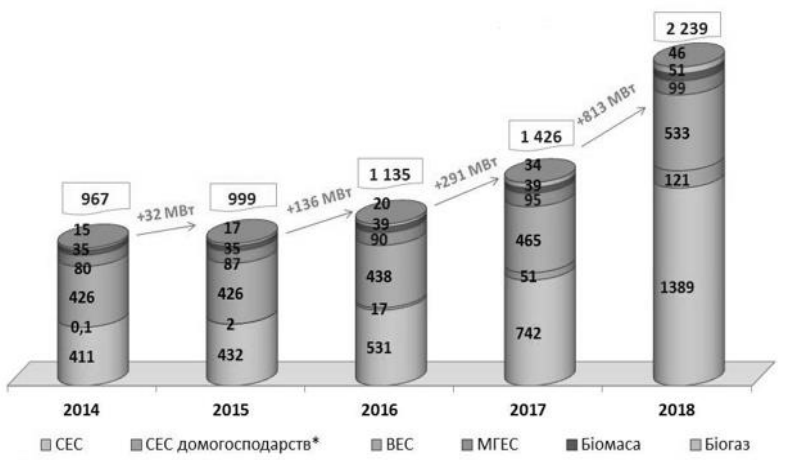

Рис. 1. Динаміка приросту потужностей відновлюваних джерел енергії в Україні

Fig. 1. Dynamics of capacity growth of renewable energy sources in Ukraine

Відновлювана енергетика поступово збільшує свою частку в загальному енергобалансі країни про що свідчить динаміка нарощування потужностей ВДЕ (рис. 1) [2]. Зокрема, за 2018 р. введено 813 МВт нових відновлюваних потужностей, основна частка яких припала на сонячну (716 МВт) та вітрову (68 МВт). Потужність решти видів відновлюваної енергетики, введених у
ККД - коефіцієнт корисної дії;

АБ - акумуляторна батарея;

ЕМ - електромобіль.

2018 році склала 29 МВт. Значні темпи приросту об'єктів сонячної енергетики пояснюються, у першу чергу, найбільшим коефіцієнтом зеленого тарифу, що робить їх найбільш економічно привабливими для інвестора. Однак, фотоелектричний потенціал енергії Сонця в 2,95 млн т н.е. значно поступається енергетичному потенціалу вітру в 15 млн т н.е. [3]. Це, у свою чергу, свідчить про недооцінку вітроенергетики, яка може суттєво збільшити виробництво чистої електричної енергії.

Одним з варіантів швидшого освоєння енергетичного потенціалу вітру та, відповідно, отримання додаткового виробітку екологічно чистої енергії $є$ використання ВЕУ для заряду різних типів електромобілів (як повністю електричних, так і гібридів, що здатні підзаряджатись). У даній роботі розглядаються економічні питання використання енергії вітру при застосуванні в складі автономної зарядної станції електромобілів (АЗСЕМ) вітроелектричних установок.

Метою даної роботи є встановлення економічної доцільності розширення використання енергетичного потенціалу вітру через застосування у складі автономних зарядних станцій вітроелектричних установок, як основних генераторів електричної енергії для заряду електромобілів.

Статистика показує [4], що ринок електромобілів в Україні продовжує бути таким, що швидко зростає. Станом на 01.11.2018 року в Україні нараховується вже понад 11,5 тисяч електромобілів (рис. 2), більше 9,5 тис. чисто електричних (BEV) та більше 2 тис. підзаряджуваних гібридів (PHEV), тоді як в 2014 році було лише 
95. На сьогодні в Україні вже $\epsilon$ понад 2000 зарядних станцій, однак практично всі вони приєднані до об'єднаної енергосистеми країни (OEC). Зростання потужних одиничних зарядних станцій електромобілів (від 100 кВт і більше) та їх кількості може призводити до значного впливу на роботу ОЕС України.

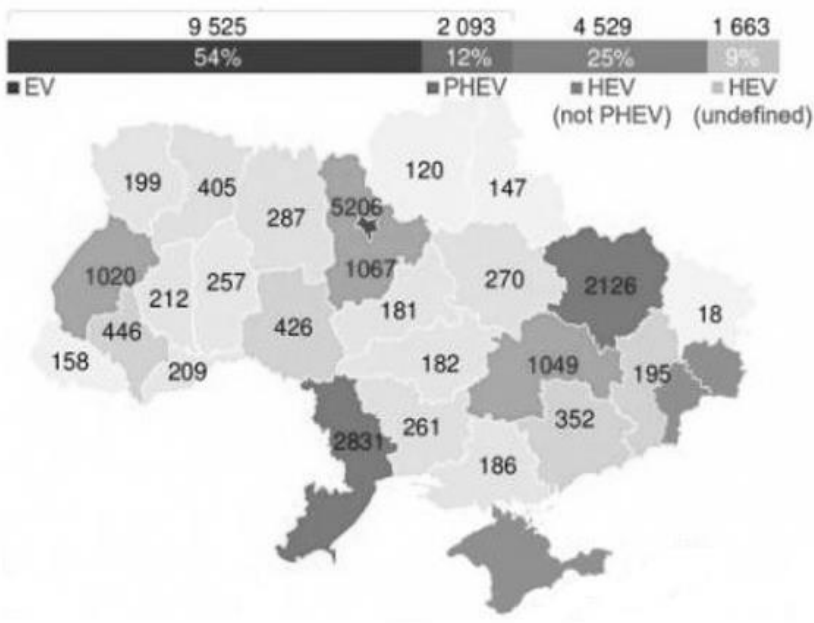

Рис. 2. Розподіл ринку електромобілів в Україні

Fig. 2. Distribution of the market of electric vehicles in Ukraine

Для розрахунків приймемо середнє споживання електроенергії одним електромобілем на рівні близько 80 кВт·год на день (близько 30 МВт.год на рік). Також у розрахунок будемо включати техніко-економічні характеристики станцій швидкого заряду (технології Chademo або SSC - 3 режимами швидкої підзарядки (100 кВТ за 10-30 хвилин)). Ставимо задачу забезпечити зниження негативного впливу на роботу ОЕС шляхом створення автономних зарядних станцій електромобілів на основі вітроелектричних установок, які розміщуватимуться на основних автошляхах досить далеко від ліній електропередачі.

Встановлення АЗСЕМ на основі ВЕУ має передбачатись у місцях 3 наявним попитом електромобілів на підзаряд при забезпеченні умов гарантованого заряду та зручності для під'їду електромобілів. Лише за умови максимально можливої експлуатації встановленої потужності генеруючого та перетворювального устаткування можуть бути досягнуті мінімальні терміни окупності витрат власника станції підза-рядки на ії проектування, монтаж і експлуатацію.

Аналіз динаміки вартості ВЕУ [5] показує, що середня вартість 1 кВт встановленої потужності станом на 2018 рік становить близько 1000 дол. США (рис. 3). Для розрахунків приймаємо вартість в 1,0 дол. США за 1 Вт встановленої потужності ВЕУ.

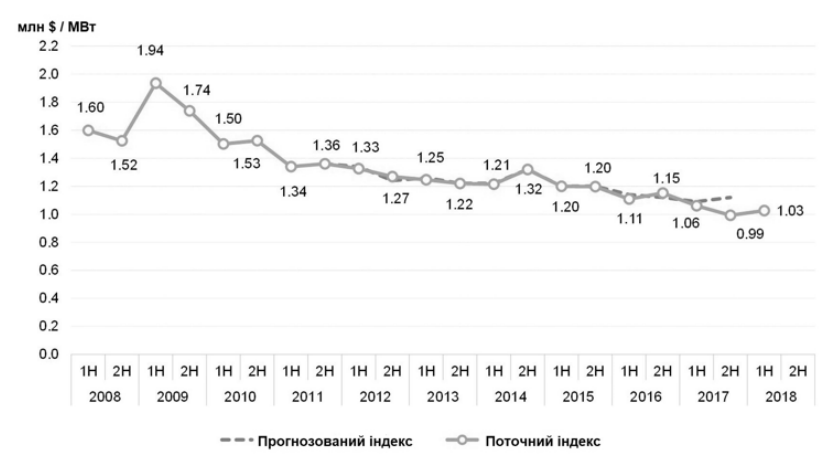

Рис. 3. Динаміка індексу вартості вітроелектричних установок

Fig. 3. Dynamics of the cost index of the wind turbines

Очікувано, що основний обсяг споживання енергії на АЗСЕМ буде спостерігатися у світлу пору доби, адже трафік у день набагато більший аніж у ночі. Зважаючи на це, автономна зарядна станція електромобілів на основі ВЕУ передбачає в своєму складі буферний акумулятор, який буде заряджатись у період наявності вітру. Незалежно від того, коли прибуде електромобіль на заряд, має бути достатньо енергії для його підзарядки. Згідно [3] ККД кращих вітрових коліс знаходиться у межах $0,3 \div 0,35$. Прийнявши ККД 0,3 ВЕС встановленою потужністю 20 кВт у середньому за рік, приміром, для регіону, наприклад м. Мелітополь, Запорізької області, Україна при висоті опори 66 м можливо отримати виробіток

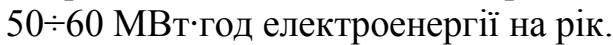

Для розрахунку необхідної потужності обираємо зарядну станцію на два підключення потужністю 100 кВт.

У даній статті будемо вважати, що виконуються такі попередні умови:

1) власні потреби АЗСЕМ (освітлення та ін.) на рівні 3 кВт·год на день;

2) залишковий заряд АБ ЕМ при заїзді електромобіля на зарядну станцію становить $20 \%$ від його максимального значення, тобто $0,2 \cdot \mathrm{E}_{\mathrm{AB}}^{\mathrm{EM}}$, оскільки при менших залишкових значеннях заряду акумулятора електромобіль може не доїхати до зарядної станції;

3) ймовірність заїзду електромобілю на зарядну станцію при залишковому заряді АБ ЕМ від $80 \%$ і більше рівна 0, оскільки дозаряд електромобіля у діапазоні від $(0,8 \div 1) \mathrm{E}_{\mathrm{AБ}}^{\mathrm{EM}}$ необхідно проводити в стаціонарному (не прискореному) режимі заряду;

4) надлишкова енергія буферної АБ АЗСЕМ повинна становити не менше $20 \%$ від номінального значення, тобто $k_{H E}=1,2$;

5) максимальне значення напруги буферної АБ ЕЗСЕМ приймаємо рівним $U_{A B}^{E У \Phi}=600 B$, згідно [4]; 
6) приймемо для розрахунків коефіцієнт корисної дії буферної акумуляторної батареї рівним $80 \%\left(\eta_{A B}^{5 У \phi}=0,8\right)$, а коефіцієнт заряду акумуляторної батареї електромобіля - рівним 90\% $\left(\eta_{A b}^{3}=0,9\right)$.

У такому випадку енергія буферної АБ для гарантованого забезпечення роботи АЗСЕМ при заряді одного ЕМ з максимальною потребою в 80 кВт·год повинна становити:

$$
\begin{gathered}
E_{A B}^{E V \Phi}=k_{3 E} \cdot \frac{E_{B I}^{A 3 C E M}+E_{A B}^{E M}}{\eta_{A B}^{B V \Phi}}= \\
=1,2 \cdot \frac{3+\frac{80}{0,9}}{0,8}=137,83 \mathrm{KBm} \cdot 20 \partial .
\end{gathered}
$$

При потребі виробітку 137,83 кВт·год щодоби (або 50,37 МВт·год на рік) необхідна встановлена потужність ВЕС має складати близько 20 кВт. При цьому, на продаж для заряду ЕМ використовуватиметься 89 кВт.год на день, або 32485 кВт.год на рік. Решта (17885 кВт·год) витрачатиметься на власні потреби АЗСЕМ, а також це будуть втрати при перетворенні та передачі енергії від ВЕУ до кінцевого споживача.

Якщо врахувати випадковий характер виробітку електроенергії ВЕУ як протягом доби, так i в сезонному розрізі, то для літньої пори року необхідно збільшувати потужність ВЕУ, оскільки в ці місяці року спостерігаються дещо менші швидкості вітру. Тобто, для літного періоду року встановлена потужність ВЕУ необхідна для забезпечення щоденного заряду електромобіля i власних потреб АЗСЕМ зросте в $1,5 \div 2$ рази.

Орієнтовна вартість ВЕУ для АЗСЕМ, при рівномірному розподілі швидкості вітру (в ідеальному випадку) буде становити:

$$
\begin{gathered}
B_{B E Y}=1000 \cdot 20=20000 \$ . \\
\text { або } \\
B_{B E Y}=20000 \cdot 28=560000 \text { грн. }
\end{gathered}
$$

Окрім вартості ВЕУ, необхідно врахувати вартість зарядних пристроїв і акумуляторів. Згідно [6] приведена вартість пристрою швидкого заряду становить $200 \$ / \kappa В$, або 5600 грн/кВт. Відповідно, зарядну станцію на 100 кВт можна оцінювати в $20000 \$$, або в 560 тис. грн.

Аналіз динаміки вартості літієвих акумуляторних батарей в період з 2010 по 2017 роки включно показує стабільну динаміку зменшення вартості 1 кВт·год від 1000\$ до 209\$ відповідно (рис. 4) [7]. Якщо прийняти вартість 1 кВт·год у 209\$, або 5852 грн, то вартість буферної АБ для АЗСЕМ енергомісткістю 138 кВт.год складає 807,576 тис. грн.

Для забезпечення заряду електромобіля у 80 кВт.год та забезпечення власних потреб зарядної станції необхідна буферна акумуляторна батарея енергоємністю в 138 кВт·год.

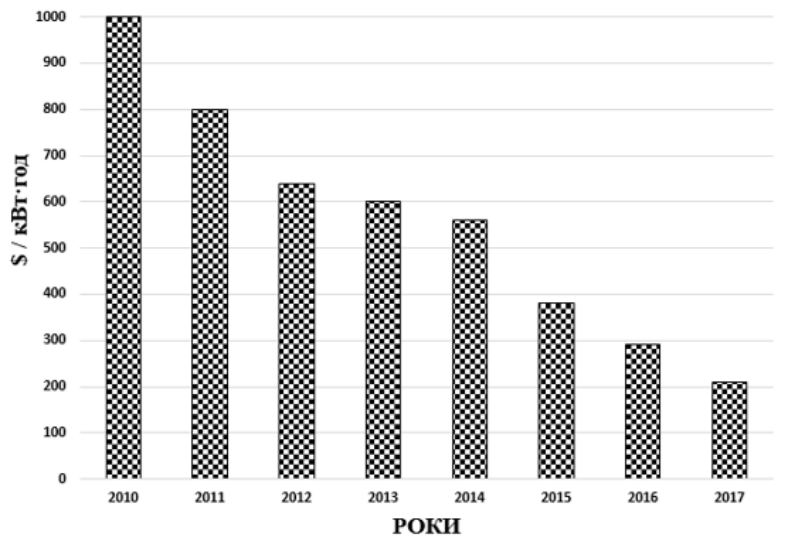

Рис. 4. Динаміка індексу вартості літісвих акумуляторних батарей

Fig. 4. Dynamics of the cost index of lithium storage batteries

Враховуючи основні витрати на реалізацію АЗСЕМ на основі ВЕУ з буферним акумулятором енергії, маємо загальну вартість близько 1,927 млн грн. До цього варто додати вартість землі, монтаж, налагодження і експлуатацію зарядної станції в межах 25\% від капітальних вкладень. Тобто, повна реалізація АЗСЕМ на основі ВЕУ 3 буферним акумулятором енергії 3 розрахунку на гарантований заряд одного електромобіля 3 максимальною енергоємністю 80 кВт год складе біля 2,5 млн грн.

При реалізації електроенергії на швидкий заряд електромобілів за нічним тарифом по 4 грн за 1 кВТ.год [8] термін окупності АЗСЕМ на основі ВЕУ складе біля $19 \div 20$ років.

Якщо реалізовувати електроенергію на станціях швидкого заряду за денним тарифом по 8 грн за 1 кВт·год швидкого заряду [8], то термін окупності станції в цілому скорочується до 9,5 -10 років, що представляє дані зарядні станції достатньо привабливою сферою інвестицій, однак за даним показником вони (АЗСЕМ на основі $\mathrm{BEУ),} \mathrm{поки} \mathrm{що,} \mathrm{поступаються} \mathrm{зарядним} \mathrm{станціям,}$ під'єднаним до ОЕС, що пояснюється додатковими витратами на ВЕУ та буферний акумулятор. Також зазначимо, що витрати на інфраструктуру, яка потрібна для зарядних станцій на ВЕУ, приймаємо такими ж як і для традиційних АЗС (під'їзд, освітлення, розмітка, знаки, вказівники тощо).

Висновки. 1. Проаналізовано динаміку нарощування встановленої потужність об'єктів відновлюваної енергетики та встановлено, що динаміка використання вітроенергетичного потенціалу України значно поступається освоєнню сонячного енергопотенціалу, що пояснюється більшою інвестиційною привабливістю фотоелектричних станцій через високий «зелений тариф» на продаж електроенергії від них, однак за питомими показниками енергетичний потенціал 
вітру більш ніж в 5 разів перевищує фотоелектричний сонячний потенціал.

2. Проведено попередню вартісну оцінку автономної зарядної станції електромобілів на основі вітроелектричних установок і встановлено, що сумарна вартість системи може становити близько 2,5 млн грн, або 89,3 тис. дол. США (за курсом початку 2019 року).

3. Термін окупності АЗСЕМ на основі ВЕУ буферним акумулятором енергії може коливатись від 9-10 років до 19-20 років залежно від вартості електроенергії, яка реалізовуватиметься для заряду електромобілів.

1. Результати роботи ринку електроенергії в 2018 році. Електронний ресурс. Режим доступу: https://biz.censor.net.ua/resonance/3106395/rezultati_roboti_rink u_elektroenerg_v_2018_rots.

2. У 2018 р. введено майже у 3 рази більше нових потужностей відновлюваної електроенергетики, ніж у 2017 році. Електронний ресурс. Режим доступу: http://saee.gov.ua/uk/news/2731.

3. Кудря С.О. Нетрадиційні та відновлювані джерела енергії. Підручник. Київ. Національний технічний університет України («КПІ»). 2012. 495 с.

4. Аналіз ринку електромобілів. Електронний ресурс. Режим доступу: http://irsgroup.com.ua/ecars.

5. Wind Turbine Price Index. Інтернет ресурс. Режим доступу: https://about.bnef.com/blog/2h-2017-wind-turbine-priceindex/.

6. Rogozhin, Alex \& Gallaher, Michael \& Helfand, Gloria \& McManus, Walter, 2010. "Using indirect cost multipliers to estimate the total cost of adding new technology in the automobile industry". International Journal of Production Economics. Elsevier, vol. 124(2). pages 360-368. April.

7. Lithium-ion battery pack costs worldwide between 2010 and 2018 (in U.S. dollars per kilowatt hour). Інтернет ресурс. Режим доступу: https://www.statista.com/statistics/ 883118/global-lithium-ion-battery-pack-costs/.

8. Електрика для електромобілів в Україні стає платною. Інтернет ресурс. Режим доступу:

https://auto.24tv.ua/elektryka_dlia_elektromobiliv_v_ukraini_sta ie_platnoiu_n3167.

\section{ЭКОНОМИЧЕСКИЕ АСПЕКТЫ РЕАЛИЗАЦИИ АВТОНОМНЫХ ЗАРЯДНЫХ СТАНЦИЙ ЭЛЕКТРО- МОБИЛЕЙ НА ОСНОВЕ ВЕТРОЭЛЕКТРИЧЕСКИХ УСТАНОВОК}

В.И. Будько ${ }^{1,2}$, канд. техн. наук, доцент; С.А. Кудря ${ }^{2,1}$, чл.корр. НАН Украины докт. техн. наук, профессор;

С.В. Войтко ${ }^{1}$, докт. экон. наук, профессор;

А.А. Трофименко ${ }^{1}$, канд. экон. наук, доцент

${ }^{1}$ Национальный технический университет Украины «Киевский политехнический институт им. Игоря Сикорского» 03056 м. Киев, пр-т Победы, 37

${ }^{2}$ Институт возобновляемой энергетики НАН Украины, 02094 м. Киев, ул. Гната Хоткевича, 20A

Проанализированы объемы выработки электроэнергии в Украине за прошльй год, а также динамику прироста электропотребления по сравнению с предыдущим годом. Рассмотрено современное состояние объектов возобновляяемой энергетики Украины и отмечено, что существенный прирост фотоэлектрических и ветроэлектрических станиий определяется высокими коэффициентами «зеленого тарифа», которые действуют на продажу экологически чистой электроэнергии. При этом показано, что темпь роста мощностей ветроэлектрических станиий существенно уступают фотоэлектрическим станциям. Отмечено, что ветроэнергетический потенциал Украины значительно превышает энергетический потенциал солнечного излучения. Учитывая быстро растущую динамику прироста электромобилей на территории Украины обоснована необходимость ускорения темпов использования энергетического потенииала ветра путем реализачии автономных зарядных станций электромобилей с ветроэлектрическими установками. Рассмотрена падающая динамика индекса стоимости ветроэлектрических установок и литиевых аккумуляторных батарей. Определены основные капиталовложения для реализаиии системы автономной зарядной станции электромобиля с ветроэлектрическими установками и буферными аккумуляторами энергии. На основе анализа сезонного характера изменения выработки ветроэлектрических установок, а также тарифной политики на продажу электрической энергии при заряде электромобилей установлено, что срок окупаемости реализации автономной зарядной станиии данного типа может составлять от 9-10 до 19-20 лет. Отмечено, что показатель гарантированного заряда электромобиля будет максимальным только при условии равномерного распределения скорости ветра в течение года. Библ. 8, рис. 4.

Ключевые слова: ветроэлектрическая установка, автономная зарядная станция, электромобиль, буферная аккумуляторная батарея.

\section{REFERENCES}

1. Rezultaty roboty rynku elektroenerhii v 2018 rotsi. [Results of the electricity market in 2018]. Electronic resource. Retrived from https://biz.censor.net.ua/resonance/3106395/ rezultati_roboti_rinku_elektroenerg_v_2018_rots [in Ukrainian].

2. U 2018 r. vvedeno maizhe u 3 razy bilshe novykh potuzhnostei vidnovliuvanoi elektroenerhety-ky, nizh u 2017 rotsi. [In 2018, almost 3 times more new renewable energy sources were introduced than in 2017]. Electronic resource. Retrived from http://saee.gov.ua/uk/news/2731 [in Ukrainian].

3. Kudria S.O. Netradytsiyni ta vidnovlyuvani dzherela enerhiyi. [Unconventional and renewable sources of energy]. Pidruchnyk. Kyiv: Natsionalnyi tekhnichnyi universytet Ukrainy («KPI»). 2012. 495 p. [in Ukrainian].

4. Analiz rynku elektromobiliv. [Analysis of the market of electric vehicles]. Electronic resource. Retrived from http://irsgroup.com.ua/ecars [in Ukrainian].

5. Wind Turbine Price Index. Internet resource. Retrived from https://about.bnef.com/blog/2h-2017-wind-turbine-priceindex/ [in English].

6. Rogozhin, Alex \& Gallaher, Michael \& Helfand, Gloria \& McManus, Walter. Using indirect cost multipliers to estimate the total cost of adding new technology in the automobile industry. International Journal of Production Economics. Elsevier. 2010. April. vol. 124(2). Pp. 360-368. [in English].

7. Lithium-ion battery pack costs worldwide between 2010 and 2018 (in U.S. dollars per kilowatt hour). Internet resource. Retrived from https://www.statista.com/statistics/883118/ global-lithium-ion-battery-pack-costs/ [in English].

8. Elektryka dlia elektromobiliv v Ukraini staie platnoiu. [Electricity for electric cars in Ukraine becomes paid]. Internet resource. Retrived from https://auto.24tv.ua/ elektryka_dlia_elektromobiliv_v_ukraini_staie_platnoiu_n3167 [in Ukrainian]. 